\title{
Częstość hospitalizacji pacjentów z bólami krzyża w Polsce na tle krajów europejskich
}

\section{Frequency of hospitalization due to low back pain syndrome in Poland and European countries}

\author{
Rafał Michalik', Małgorzata Kowalska², Przemysław Kotyla ${ }^{3}$, Aleksander J. Owczarek ${ }^{4}$ \\ ${ }^{1}$ Dział Fizjoterapii Sosnowieckiego Szpitala Miejskiego \\ ul. Szpitalna 1, 41-219 Sosnowiec \\ Kierownik: Andrzej Brożek \\ ${ }^{2}$ Katedra i Zakład Epidemiologii Śląskiego Uniwersytetu Medycznego w Katowicach \\ ul. Medyków 18, 40-752 Katowice \\ Kierownik: prof. dr hab. n. med. Jan E. Zejda \\ ${ }^{3}$ Katedra i Klinika Chorób Wewnętrznych i Reumatologii Śląskiego Uniwersytetu Medycznego w Katowicach \\ ul. Ziołowa 45/47, 40-635 Katowice \\ Kierownik: prof. dr hab. n. med. Eugeniusz Kucharz \\ ${ }^{4}$ Zakład Statystyki Katedry Analizy Instrumentalnej Śląskiego Uniwersytetu Medycznego w Katowicach \\ ul. Ostrogórska 30, 41-200 Sosnowiec \\ Kierownik: dr hab. n. o zdr. Aleksander J. Owczarek
}

\section{SUMMARY}

Introduction: Back pain is one of the most frequently diagnosed diseases of the osteoarticular system. It has been estimated that $50-80 \%$ of the population has experienced at least one episode of back pain.

The aim of the study was to present the epidemiology data on back pain in Poland based on secondary epidemiological data collected in national and international databases.

Materials and methods: The study was based on the data provided by the National Institute of Health under the framework of the National Hospital Morbidity Research, and the data collected in the Eurostat database.

Results: Currently, the highest prevalence rates of hospital admission due to back pain are found in the oldest women (over 65 years) and slightly younger men (between 55 and 64 years of age). In the group of people older than 45 years the incidence of

\section{STRESZCZENIE}

Wstęp: Ból grzbietu jest jedną z najczęściej rozpoznawanych chorób układu kostno-stawowego. W ciągu życia co najmniej jeden epizod bólu grzbietu wystąpi u 50-80\% populacji. Celem pracy było przedstawienie sytuacji epidemiologicznej w zakresie bólu grzbietu w Polsce na podstawie wtórnych danych gromadzonych w zasobach krajowych i międzynarodowych. Materiał i metody: W pracy wykorzystano dane udostępniane przez Państwowy Zakład Higieny w ramach Ogólnopolskiego Badania Chorobowości Szpitalnej Ogólnej oraz dane gromadzone w bazie danych Eurostatu.

Wyniki: Aktualnie największe wartości współczynnika chorobowości szpitalnej z powodu bólu grzbietu dotyczą najstarszych kobiet (po 65. r.ż.) i nieco młodszych mężczyzn (pomiędzy 55 a 64. r.ż.). W grupie osób po 45. r.ż. częstość epizodów wzrasta ok. 3-krotnie w stosunku do osób młodszych, ponadto większa pain episodes increases to about threefold compared to younger people. Moreover, it is noted that the higher number of hospitalizations due to low back pain syndrome concerns rural residents. The analysis of the Eurostat data indicates a large variation in rates of hospitalization due to lower back pain and a slightly different course of disease in other countries. In Poland, for both women and men, there has been a steady increase in the number of patients hospitalized due to lower back pain. Conclusions: The hospitalization rate due to back pain in Poland is one of the lowest in Europe, but the observed increase in the number of hospitalized patients in recent years has created a significant economic burden in the healthcare system. It is worth noting that an average length of hospitalization of patients with lower back pain is slightly longer in Poland (on average 4 days longer) than in Western European countries. Key words: lower back pain syndrome, M54 ICD-10. liczba hospitalizacji z powodu bólów krzyża dotyczy mieszkańców wsi. Analiza danych Eurostatu wskazuje na dużą zmienność współczynnika hospitalizacji z powodu bólu grzbietu w czasie i nieco odmienny przebieg tych zmian w poszczególnych krajach. W Polsce zarówno w przypadku kobiet, jak i mężczyzn notuje się regularny wzrost liczby chorych hospitalizowanych z powodu bólu grzbietu.

Wnioski: Współczynnik hospitalizacji z powodu bólu grzbietu w Polsce należy do jednego z niższych w Europie, ale obserwowany wzrost liczby hospitalizowanych w kolejnych latach przyczynia się do znacznego ekonomicznego obciążenia systemu opieki zdrowotnej. Uwagę zwraca nieco dłuższy średni czas hospitalizacji chorych z bólem grzbietu w Polsce (średnio o 4 dni w stosunku do państw Europy Zachodniej).

Słowa kluczowe: bóle krzyża, zespół bólowy dolnego odcinka kręgosłupa, bóle pleców, M54 ICD-10. 
W związku z postępującym procesem starzenia się populacji, a także w odpowiedzi na istotne zmiany trybu życia i sposobu pracy, które obserwowane są w ostatnich latach, notuje się wzrost problemów zdrowotnych w obrębie układu kostno-stawowego, mięśniowego oraz tkanki łącznej. Choroby te mają znamiona chorób przewlekłych, a ich długotrwałe leczenie pociąga za sobą wzrost kosztów opieki zdrowotnej. Pogorszenie stanu zdrowia pracowników sprzyja nie tylko spadkowi wydajności pracy i występowaniu absencji, ale prowadzić może także do rozwoju inwalidztwa oraz pogorszenia jakości życia $[1,2]$.

Ból grzbietu (M54 wg klasyfikacji ICD-10) jest jedną z najczęściej rozpoznawanych chorób układu kostno-stawowego. Na podstawie różnych szacunków ocenia się, że w ciągu życia co najmniej jeden epizod bólu grzbietu wystąpi u 50-80\% osób z populacji. Ból krzyża to w zasadzie zespół objawów towarzyszących licznym chorobom reumatycznym, neurologicznym oraz ortopedycznym. Wśród przyczyn bólu wymienia się te zwyrodnieniowe (ból grzbietu mechaniczny), jednakże objawy pojawiają się także w wyniku postępującego procesu zapalnego w obrębie struktur kręgosłupa (zapalny ból kręgosłupa).

Celem pracy było przedstawienie sytuacji epidemiologicznej w zakresie bólu grzbietu w Polsce na podstawie w tórnych danych gromadzonych w zasobach krajowych i międzynarodowych, a także poznanie aktualnej wiedzy na temat uwarunkowań dolegliwości bólowych związanych z bólem krzyża.

\section{MATERIA $~ I$ METODY}

W pracy wykorzystano dane udostępniane przez Państwowy Zakład Higieny (PZH) w ramach Ogólnopolskiego Badania Chorobowości Szpitalnej Ogólnej za lata 2003-2011. Podstawowym źródłem informacji o chorobowości w Polsce jest karta statystyczna szpitalna Mz/Szp-11 i zawarty w niej zestaw informacji, z wyłączeniem danych personalnych pacjenta, przesyłany przez poszczególne szpitale do Narodowego Instytutu Zdrowia Publicznego - PZH w Warszawie. Dane te pozwalają ustalić liczbę chorych z powodu danej przyczyny w populacji ogółem oraz w poszczególnych grupach wiekowych, a także z uwzględnieniem płci i miejsca zamieszkania (miasto/wieś). Jednocześnie stwarzają sposobność do śledzenia czasu trwania leczenia szpitalnego poszczególnych chorób. Z kolei dla porównania częstości występowania bólu grzbietu w populacji w Polsce i w Unii Europejskiej wykorzystano dane gromadzone w bazie danych Eurostatu za lata 2000-2011 [3]. Ostatecznie dla ustalenia uwarunkowań przyczynowo-skutkowych dolegliwości bólowych grzbietu dokonano przeglądu piśmiennictwa dostępnego w bazie Pubmed. Korzystano z następujących słów kluczowych: bóle krzyża, bóle pleców, M54 ICD-10, zespół bólowy dolnego odcinka kręgosłupa.

\section{WYNIKI}

W tabeli 1 przedstawiono trendy współczynnika hospitalizacji z powodu bólu grzbietu w latach 2003-2011, w poszczególnych grupach wiekowych w Polsce. Istotnym aspektem jest gwałtowny wzrost wartości współczynnika, który wystąpił niezależnie od wieku badanych w 2008 r. W ostatnich latach największe wartości współczynnika chorobowości szpitalnej z powodu bólu grzbietu dotyczyły najstarszych kobiet (po 65. r.ż.) i nieco młodszych mężczyzn (pomiędzy 55. a 64. r.ż.). Warto także zauważyć, że w grupie osób powyżej 45. r.ż. częstość epizodów wzrasta ok. 3-krotnie w stosunku do osób młodszych.

Na rycinie 1 zaprezentowano współczynnik chorobowości szpitalnej z powodu bólów krzyża w Polsce, w przeliczeniu na 10 tys. mieszkańców miast i wsi. Warto zauważyć, że większa liczba hospitalizacji osób dorosłych z powodu bólów dotyczyła mieszkańców wsi. Największe dysproporcje pomiędzy wartością współczynnika dla wsi i miasta odnotowano w grupie wiekowej 45-54 lat oraz 55-64 lat, natomiast po osiągnięciu wieku 65 lat współczynniki ulegają zrównaniu.

TABELA 1. Współczynnik hospitalizacji (n/10 tys.) z powodu bólu grzbietu w grupie kobiet i mężczyzn w Polsce w poszczególnych grupach wiekowych w latach 2003-2011

\begin{tabular}{|c|c|c|c|c|c|c|c|c|c|c|}
\hline Płeć & Wiek & 2003 r. & 2004 r. & 2005 r. & 2006 r. & 2007 r. & 2008 r. & 2009 r. & 2010 r. & 2011 r. \\
\hline \multirow{6}{*}{ Kobiety } & 15-19 & 1,3 & 1,2 & 1,4 & 1,6 & 1,7 & 3,1 & 3,1 & 3,3 & 3,4 \\
\hline & $20-34$ & 1 & 0,8 & 1 & 1,1 & 1,1 & 1,7 & 2 & 2,3 & 2,3 \\
\hline & $35-44$ & 2,5 & 2,2 & 2,2 & 2,2 & 2,6 & 4,5 & 5 & 5,5 & 4,9 \\
\hline & $45-54$ & 4,4 & 3,6 & 3,7 & 4,1 & 3,9 & 8,5 & 8,7 & 8,9 & 8,2 \\
\hline & $55-64$ & 3,6 & 2,8 & 2,7 & 3,5 & 3,6 & 8,9 & 8,9 & 9,2 & 8,6 \\
\hline & $\geq 65$ & 3,3 & 2,8 & 3 & 3,5 & 3,4 & 10,6 & 10,7 & 10,7 & 10,8 \\
\hline \multirow{5}{*}{ Mężczyźni } & 15-19 & 0,7 & 0,7 & 0,7 & 0,9 & 1,1 & 1,6 & 1,8 & 1,9 & 2,1 \\
\hline & $20-34$ & 1 & 1 & 1,2 & 1,4 & 1,3 & 1,9 & 2,3 & 2,7 & 2,9 \\
\hline & $35-44$ & 2,9 & 2,6 & 2,9 & 3,1 & 2,7 & 4,4 & 4,9 & 4,7 & 4,8 \\
\hline & $45-54$ & 4,2 & 3,5 & 3,7 & 4,3 & 3,8 & 7 & 7,3 & 7,6 & 6,9 \\
\hline & $55-64$ & 3,2 & 3,1 & 3 & 4,1 & 3,5 & 8,4 & 8,9 & 9,3 & 9,4 \\
\hline
\end{tabular}




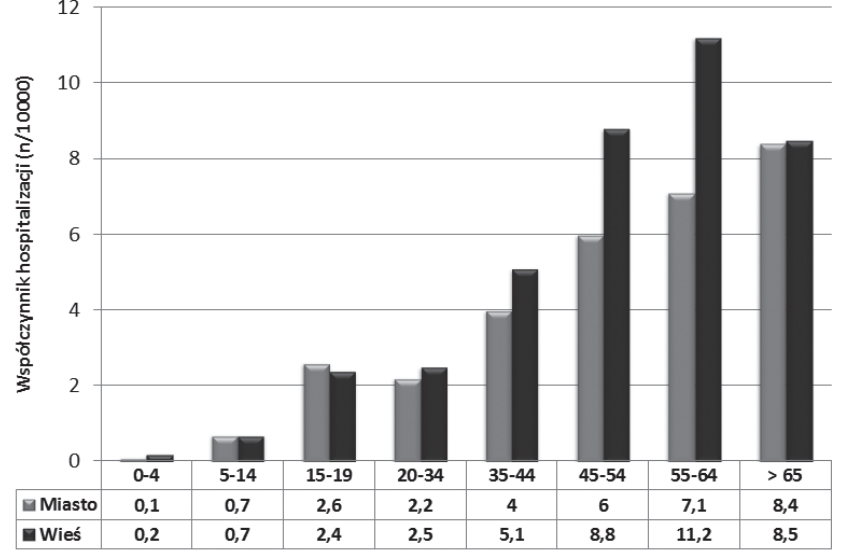

RYCINA 1. Współczynnik hospitalizacji (n/10 tys.) z powodu bólu grzbietu na wsi oraz w mieście w poszczególnych grupach wiekowych (dane z 2012 r.)

Na rycinie 2 przedstawiono współczynnik hospitalizacji (n/100 000 mieszkańców) z powodu bólu grzbietu w Polsce i w wybranych krajach Unii Europejskiej. Widoczne są znaczące różnice w liczbie chorych hospitalizowanych z powodu bólów krzyża. Największe współczynniki rejestruje się w Austrii, Republice Czeskiej i w Niemczech, natomiast Polska należy do krajów o niskiej wartości współczynnika hospitalizacji. Analiza danych Eurostatu z okresu 2000-2011 wskazuje na dużą zmienność współczynnika hospitalizacji z powodu bólu grzbietu w czasie i nieco odmienny przebieg tych zmian w poszczególnych krajach. Warto podkreślić, że w Polsce zarówno w przypadku kobiet, jak i mężczyzn notuje się regularny wzrost liczby chorych hospitalizowanych z powodu bólu grzbietu. Stały poziom hospitalizacji jest obserwowany w takich krajach jak: Irlandia, Hiszpania, Szwecja i Wielka Brytania, natomiast spadek odnotowano m.in. w Austrii i Republice Czeskiej.

W tabeli 2 przedstawiono zmiany rejestrowane w zakresie średniego czasu trwania hospitalizacji z powodu bólu grzbietu w latach 2003-2011 w Polsce, w poszczególnych grupach wiekowych pacjentów. W analizowanym okresie zaobserwowano
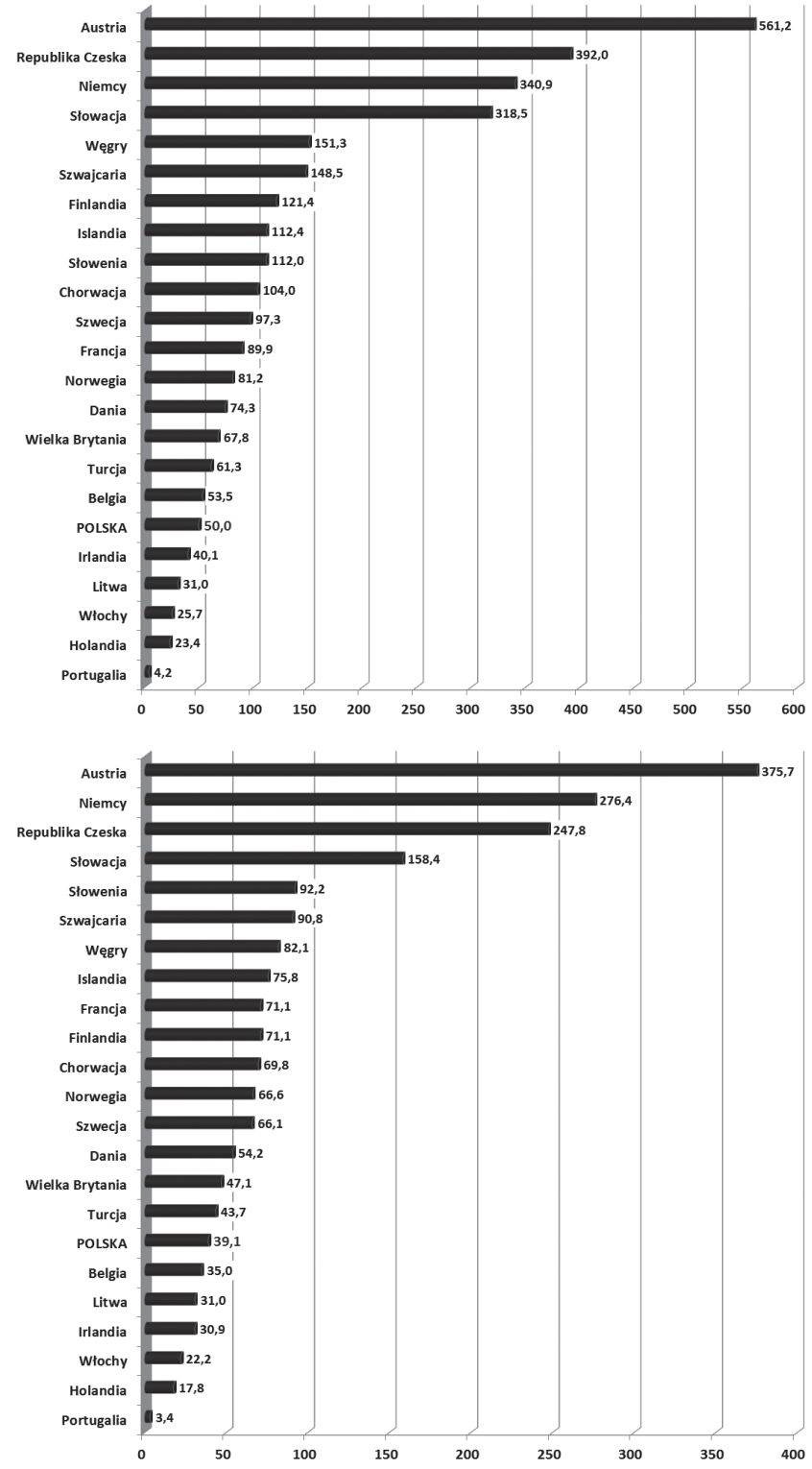

RYCINA 2. Współczynnik hospitalizacji z powodu bólu grzbietu (n/100 tys. mieszkańców) w grupie kobiet (u góry) i mężczyzn (na dole) w Polsce i wybranych krajach Unii Europejskiej w 2012 r.

TABELA 2. Średni czas trwania hospitalizacji (w dniach) z powodu bólu grzbietu w grupie kobiet i mężczyzn w Polsce w poszczególnych grupach wiekowych w latach 2003-2011

\begin{tabular}{|c|c|c|c|c|c|c|c|c|c|c|}
\hline Płeć & Wiek & 2003 r. & 2004 r. & 2005 r. & $2006 \mathrm{r}$. & 2007 r. & $2008 \mathrm{r}$. & 2009 r. & 2010 r. & $2011 \mathrm{r}$. \\
\hline \multirow{6}{*}{ Kobiety } & 15-19 & 10,8 & 9,4 & 9,3 & 9 & 7,4 & 6,9 & 6,6 & 7,2 & 6,3 \\
\hline & $20-34$ & 9,5 & 9,9 & 8,8 & 9,1 & 7,6 & 8,1 & 6,7 & 5,8 & 5,3 \\
\hline & $35-44$ & 10,5 & 11,8 & 10,5 & 10,5 & 10,5 & 11,4 & 9,3 & 8,4 & 7,4 \\
\hline & $45-54$ & 11,1 & 12,4 & 11,7 & 12,3 & 11,8 & 13,8 & 11,3 & 10,7 & 9,7 \\
\hline & $55-64$ & 12 & 14,1 & 12,1 & 12,1 & 13 & 14,7 & 12,3 & 12,7 & 11,1 \\
\hline & $\geq 65$ & 13,5 & 13,3 & 11,9 & 12 & 12,6 & 14,7 & 12,6 & 12,5 & 11 \\
\hline \multirow{6}{*}{ Mężczyźni } & $15-19$ & 8,5 & 9,4 & 10,6 & 7,7 & 6,2 & 6,3 & 7,3 & 4,9 & 6,4 \\
\hline & $20-34$ & 8,8 & 9 & 10,7 & 7,4 & 7,2 & 6,9 & 5,8 & 5 & 3,9 \\
\hline & $35-44$ & 10,3 & 11,5 & 11,7 & 9,6 & 9 & 9,5 & 7,6 & 7,1 & 5,7 \\
\hline & $45-54$ & 10,4 & 11,7 & 12,3 & 10,8 & 10,4 & 11,7 & 9,8 & 9,1 & 8,2 \\
\hline & $55-64$ & 11,3 & 11,8 & 12,8 & 10,7 & 10,5 & 13,2 & 10,2 & 10,2 & 9,5 \\
\hline & $\geq 65$ & 12,4 & 12,3 & 12,4 & 11,3 & 10,7 & 13,2 & 10,8 & 10,5 & 9,3 \\
\hline
\end{tabular}


skrócenie czasu trwania hospitalizacji niezależnie od płci i wieku za wyjątkiem 2008 r., w którym odnotowano zwiększenie średniego czasu pobytu. W grupie kobiet zanotowano spadek ogółem o 16,5\% (7,5\% w grupie 55-64 lat; 44,2\% w grupie powyżej 20-34 lat), średnio o 0,17 dnia na rok. W grupie mężczyzn spadek był większy i wynosił 27,6\% (15,9\% w grupie $55-64$ lat; $55,7 \%$ w grupie powyżej 20-34 lat), średnio o 0,41 dnia na rok. W 2011 r. średni czas pobytu w szpitalu z powodu bólu grzbietu w grupie kobiet wynosił 9,6 dni, a w grupie mężczyzn 7,6 dni.

\section{OMÓWIENIE}

Występowanie chorób reumatycznych w populacji dorosłych szacuje się na 4-5\%. Ocenia się, że wśród wszystkich chorób, choroby reumatyczne znajdują się na 8. miejscu pod względem obciążenia systemu opieki zdrowotnej [4]. Na podstawie zgromadzonego piśmiennictwa przedmiotu ustalono, że częstość występowania chorób układu kostno-stawowego wykazuje tendencję wzrostową wraz z wiekiem [5, 6]. Należy oczekiwać dalszego pogorszenia sytuacji epidemiologicznej w świetle zachodzących przemian demograficznych populacji, tj. wraz z wydłużaniem się przeciętnego dalszego trwania życia. Największa częstość występowania bólu grzbietu dotyczy aktualnie osób w przedziale wiekowym 45-65 lat (18-50\%), najmniejsza dotyczy dzieci (1-6\%) [6]. Średni czas pobytu chorego w szpitalu w Polsce jest nieco dłuższy niż w innych krajach Unii Europejskiej i w odniesieniu do kobiet różnica ta wynosi średnio o 2,1 dnia, a w odniesieniu do mężczyzn o - 0,8 dnia [3].

Szacuje się również, że występowanie częstych lub trwających dłużej niż 2 tyg. dolegliwości bólowych dolnego odcinka kręgosłupa (M54 wg klasyfikacji ICD-10) zgłasza rocznie prawie co piąta osoba dorosła (ok. 15-20\%). Ustalono także, że każdego roku 7\% populacji zgłasza się z tego powodu do lekarzy pierwszego kontaktu [7, 8]. W pracy Loney i Stratforda przedstawiono przegląd dostępnych badań analizujących częstość występowania bólu grzbietu. Oszacowano, że w krajach Europy Zachodniej bóle grzbietu występują w populacji z różną częstością, od 12\% w Szwecji, 13,7\% w Danii, 14\% w Wielkiej Brytanii, do 33\% w Belgii. W przypadku Stanów Zjednoczonych Ameryki bóle grzbietu dotyczą 6,7\% populacji, a w Kanadzie i Australii odpowiednio 28,4\% i 8\%. Rozbieżności w częstości występowania wynikają przede wszystkim z różnej definicji choroby (bólu grzbietu) przyjętej przez autorów publikowanych prac $[6,9]$. Hoy i wsp. oszacowali z kolei częstość występowania bólu grzbietu ograniczającego aktywność o co najmniej dzień; kształtuje się ona na poziomie 11,9\% $\pm 2,0 \%$ w całej populacji [10]. W kolejnym badaniu Hoy $i$ wsp. przedstawili szacunki dotyczące częstości występowania pierwszego epizodu bólu grzbietu, która mieści się w zakresie 6,3-15,4\% oraz nawrotu choroby w okresie roku - częstość ta była zdecydowanie wyższa i wynosiła 24-80\%. Wykazano, że u 54-90\% chorych dochodzi do remisji w ciągu roku, przy czym ponad $80 \%$ chorych wraca do pracy w ciągu miesiąca. Niestety stwierdzono także, że $5 \%$ pacjentów nigdy nie podejmuje już aktywności zawodowej [10,11].
Rozbieżność uzyskanych przez różnych autorów danych jest niewątpliwie efektem odmiennych czynników środowiskowych lub osobniczych badanych wpływających tak na częstość występowania, jak i przebieg dolegliwości [11,12]. Wśród uznanych czynników ryzyka wystąpienia bólu grzbietu znajdują się: starszy wiek, płeć żeńska, niski poziom wykształcenia, otyłość, stres, depresja, zaburzenia lękowe, brak satysfakcji zawodowej, niski poziom wsparcia społecznego, uwarunkowania genetyczne, palenie tytoniu i narażenie na czynniki wibracyjne, ciężka praca fizyczna, dźwiganie ciężarów oraz manipulowanie nimi, pozycje niewygodne (skręty, wyginanie ciała, pozycja statyczna) $[11,12,13]$. Wykazano również wpływ rodzaju wykonywanej pracy na ryzyko wystąpienia bólu grzbietu, przyjmując jako grupę odniesienia pracowników kadry zarządzającej i specjalistów. Dla sprzedawców i pracowników biurowych ryzyko wynosiło 1,38 (95\% CI: 0,85-2,25), dla operatorów ciężkiego sprzętu było większe i wynosiło 2,39 (95\% CI: 1,09-5,25), natomiast największe ryzyko dotyczyło pracowników gospodarstw rolnych: 5,17 (95\% CI: 1,57-17,0) [7]. Szczególnie wysokie wskaźniki występowania ciężkich schorzeń odcinka lędźwiowego stwierdza się w takich grupach zawodowych, jak: robotnicy rolni, robotnicy budowlani, cieśle, kierowcy (w tym kierowcy ciężarówek i traktorzyści), pielęgniarki, sprzątaczki [13]. Warto odnieść się również do pracy Soleckiego, który wykazał istotnie częstsze występowanie dolegliwości w obrębie dolnego odcinka kręgosłupa u rolników względem porównawczej grupy pracowników umysłowych [13]. Podobnie w badaniu własnym ujawniono większą liczbę hospitalizacji osób dorosłych z powodu bólów krzyża wśród mieszkańców wsi niż miast.

W świetle dostępnych danych z piśmiennictwa należy stwierdzić, że częstość występowania chorób układu kostno-stawowego, w tym bólów krzyża, wykazuje tendencję wzrostową wraz z wiekiem. Należy oczekiwać, że wraz ze wzrostem średniej długości życia wzrastać będzie również obciążenie systemu opieki zdrowotnej wynikające ze wzrostu liczby pacjentów z rozpoznanymi dolegliwościami bólowymi kręgosłupa, w tym chorobami reumatycznymi [4]. Ból grzbietu, oznaczony kodem M54 wg ICD-10, to w istocie kilka jednostek chorobowych, dla których wspólnym objawem osiowym jest ból jednego lub kilku odcinków kręgosłupa. Etiologia tych zespołów bólowych obejmuje zarówno zmiany zapalne tkanki podskórnej, zespoły korzeniowe oraz rwę kulszową. Prawidłowe rozpoznanie choroby nie jest łatwe, bowiem wymienione przyczyny mechaniczne i zwyrodnieniowe są trudne do odróżnienia od tych o charakterze zapalnym. Diagnoza powinna być postawiona przede wszystkim na podstawie wnikliwego badania podmiotowego (wywiadu), badania przedmiotowego (palpacji i obserwacji oraz testów prowokacyjnych) oraz ewentualnych badań dodatkowy (zdjęć rentgenowskich, tomografii komputerowej lub rezonansu magnetycznego).

Aktualne dowody naukowe potwierdzają, że w grupie osób do 45. r.ż. bóle grzbietu stanowią główną przyczynę ograniczenia codziennej aktywności życiowej i zawodowej [6]. Odległe następstwa występowania bólów grzbietu wykazują istotne zróżnicowanie pomiędzy odmiennymi populacjami. Źródłem 
tego zróżnicowania jest m.in. brak równomiernego dostępu do świadczeń opieki zdrowotnej, ale także istotne zróżnicowanie społeczno-ekonomiczne, zróżnicowany rynek pracy z możliwościami zatrudnienia, a nawet deklarowany poziom odczuwania bólu [11].

Koszty związane z chorobami układu kostno-stawowego obejmują koszty bezpośrednie, pośrednie oraz tzw. koszty niewymierne [4, 6]. Wśród kosztów bezpośrednich znajdują się m.in. koszty opieki zdrowotnej obejmujące koszty wizyt lekarskich, procedur diagnostycznych, zabiegów operacyjnych, opieki i sprzętu rehabilitacyjnego, koszty farmakoterapii i/lub leczenia hospicyjnego. Koszty osobowe obejmują z kolei koszty transportu oraz czas pacjenta i personelu medycznego zaangażowanego w proces terapeutyczny. Wreszcie inne koszty, które pokrywają wydatki związane z opieką domową, dostosowaniem miejsca zamieszkania do możliwości niepełnosprawnego, zakupem urządzeń wspomagających funkcjonowanie chorego w domu, a nawet koszty terapii alternatywnych. Koszty pośrednie związane są natomiast ze zmianą formy zatrudnienia lub nawet utratą pracy oraz zmniejszeniem dochodów, zwiększonymi wydatkami związanymi z chorobą, a wreszcie ze zmianą sposobu życia chorego (konieczność całodobowej opieki w domu lub przeniesienie chorego do domu opieki czy hospicjum). Oszacowano, że dolegliwości związane z bólem grzbietu pochłaniają (w zależności od kraju) 0,19-0,42\% produktu krajowego brutto, a ponadto stanowią 1,65-3,22\% nakładów poniesionych na opiekę zdrowotną [6]. Szacunki Światowej Organizacji Zdrowia z 2004 r. wskazują, że bóle grzbietu powodują utratę blisko 2,5 mln lat życia z powodu zgonu lub niepełnosprawności (tzw. DALYs), stanowiąc 0,09\% globalnego obciążenia chorobami [14]. W pracy przedstawionej przez Katza wyceniono koszty leczenia chorych z bólem grzbietu w Stanach Zjednoczonych. I tak koszty wizyt lekarskich wyniosły 5 mld USD, leczenie operacyjne pochłaniało 15 mld USD rocznie [12]. Z kolei w Niemczech średni roczny koszt opieki nad chorym z bólem grzbietu wyceniono na ponad 7 tys. euro [15]. Oprócz kosztów bezpośrednich istotnym aspektem są również koszty pośrednie stanowiące $2 / 3$ kosztów ogółem ponoszonych z powodu bólów grzbietu. Oszacowano, że 5\% populacji Stanów Zjednoczonych nie pojawiło się co najmniej jeden dzień w pracy z powodu bólu grzbietu oraz że choroby układu kostno-stawowego są odpowiedzialne za blisko 50 mld USD strat produkcyjnych [12].

Według danych Zakładu Ubezpieczeń Społecznych, absencja chorobowa z powodu chorób układu kostno-stawowego, mięśniowego i tkanki łącznej w Polsce w 2012 r. wyniosła ponad 28,14 mln dni. Oszacowano, że 13,6\% ogółu zarejestrowanych dni absencji chorobowej było spowodowane właśnie tymi dolegliwościami. Liczba zwolnień lekarskich z tego tytułu wynosiła 2,05 mln (12,4\% ogółu wydanych zaświadczeń), przy czym warto odnotować, że częściej zwolnienia wystawiono mężczyznom niż kobietom (odpowiednio 1,175 mln oraz 0,876 mln). Konfrontacja tej informacji z danymi o chorobowości hospitalizowanej (częściej hospitalizowane są kobiety niż mężczyźni) jest trudna do wytłumaczenia. Być może obserwowana rozbieżność wskazuje na większy udział u mężczyzn czynników mechanicznych związanych z charakterem wykonywanej pracy (praca fizyczna vs praca biurowa) przy większej niechęci mężczyzn do leczenia stacjonarnego. Warto w tym miejscu przytoczyć odnotowane w badaniu własnym interesujące spostrzeżenie o zrównaniu się współczynników hospitalizacji z powodu bólów krzyża u osób starszych (po 65. r.ż.), zamieszkałych w mieście i na wsi. Być może osiągnięcie wieku emerytalnego i ustanie aktywności zawodowej sprawiają, że osiągnięte pewne minimum bezpieczeństwa socjalnego sprawia, iż pracownik godzi się ze swoim stanem zdrowia (w tym dolegliwościami bólowymi kręgosłupa). W okresie emerytalnym nie ma również niebezpieczeństwa utraty pracy spowodowanego koniecznością hospitalizacji i przedłużającym się okresem niezdolności do pracy. Większa częstość hospitalizacji u kobiet spowodowana zespołami bólowymi kręgosłupa wpisuje się w obserwowany trend częstszego wykorzystywania zasobów opieki zdrowotnej przez kobiety. Grupa ta częściej korzysta z usług medycznych przy mniejszym nasileniu dolegliwości bólowych oraz częściej jest hospitalizowana ze wskazań diagnostycznych niż wskazują to rzeczywiste potrzeby interwencji medycznej w warunkach szpitalnych. Jeśli ta hipoteza jest słuszna, to w związku z wprowadzanymi zmianami systemowymi organizacji opieki zdrowotnej należy przypuszczać, że ograniczenie hospitalizacji diagnostycznych i przeniesienie ich ciężaru na ambulatoryjną diagnostykę oraz opiekę nad chorymi może w niedługim czasie spowodować wyrównywanie współczynników hospitalizacji dla kobiet i mężczyzn. W pracy Minty i wsp. wykazano, że ponad 78\% pacjentów ZUS stanowiły osoby korzystające ze świadczeń socjalnych poniżej roku, co świadczy o wzrastającej świadomości dysponentów w zakresie potrzeby wczesnej rehabilitacji w dysfunkcjach narządu ruchu [16].

Przeciętna długość trwania zwolnienia lekarskiego wynosiła ok. 2 tyg. (13,71 dni). Pod względem dni absencji chorobowej w pracy, choroby układu kostno-stawowego stanowiły trzecią co do częstości grupę chorób [17]. Na rycinie 3 przedstawiono rozkład odsetka dni rejestrowanej absencji w pracy z powodu chorób układu kostno-stawowego, mięśniowego

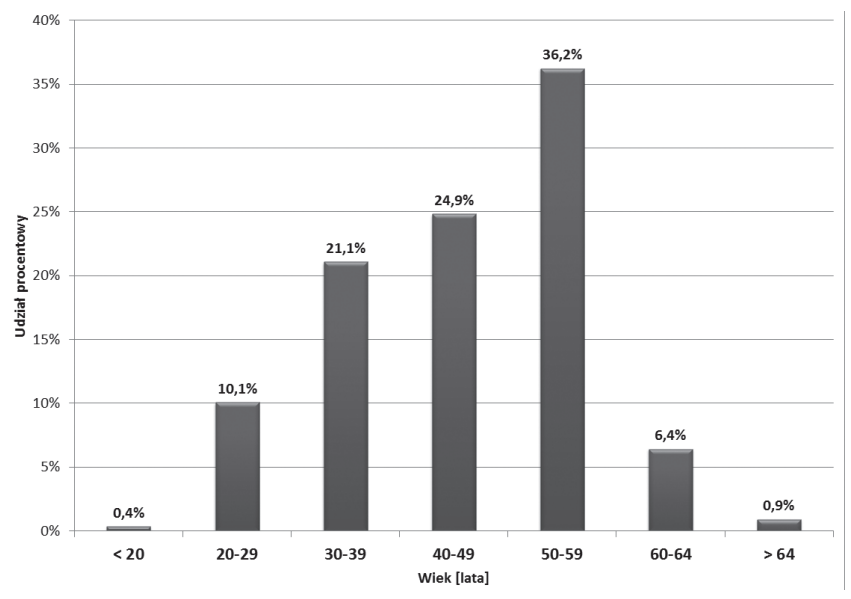

RYCINA 3. Odsetek dni rejestrowanej absencji w pracy z powodu chorób układu kostno-stawowego, mięśniowego oraz tkanki łącznej wśród wszystkich dni udzielonych zwolnień lekarskich w 2012 r. w Polsce; dane dla poszczególnych grup wiekowych 
oraz tkanki łącznej wśród wszystkich dni udzielonych zwolnień lekarskich w 2012 r. w Polsce w poszczególnych grupach wiekowych. Warto zauważyć, że w grupie osób w wieku 50-59 lat co trzeci chory $(36,2 \%)$ uzyskiwał orzeczenie o niezdolności do pracy z tytułu wymienionych chorób. Najmniejszy odsetek dotyczył osób będących w wieku przed- lub poprodukcyjnym. Rejestrowana absencja chorobowa z powodu bólu grzbietu (M54) w 2012 r. wyniosła ogółem 3,325 mln dni, przy czym w grupie mężczyzn było to $1,931 \mathrm{mln}$ dni, a w grupie kobiet 1,392 mln dni. Bóle grzbietu w grupie mężczyzn stanowiły 7. co do częstości jednostkę chorobową powodującą najdłuższą absencję chorobową, a w grupie kobiet 12. [17]. Za taki profil odpowiada prawdopodobnie charakter wykonywanej pracy. To mężczyźni częściej niż kobiety wykonują ciężką pracę fizyczną, która wymaga wymuszonej, np. stojącej pozycji ciała przy pracy, z większym obciążeniem zewnętrznym, z większą częstością powtórzeń konkretnej czynności, a także z dłuższym czasem trwania obciążenia [18].

\section{WNIOSKI}

W podsumowaniu należy stwierdzić, iż współczynnik hospitalizacji z powodu bólu grzbietu w Polsce należy do jednego z niższych w Europie, ale obserwowany wzrost liczby hospitalizowanych w kolejnych latach przyczynia się do znacznego ekonomicznego obciążenia systemu opieki zdrowotnej. Rosną także koszty pośrednie związane z kosztami pracy, szczególnie w grupie mężczyzn 55-64 lat, a więc u osób nadal aktywnych zawodowo. Warto zwrócić uwagę na te spostrzeżenia, mając na uwadze decyzję o wydłużeniu czasu pracy niezbędnego do osiągnięcia wieku emerytalnego, także w Polsce. Tym bardziej konieczne jest wdrożenie działań ochronnych, m.in. poprzez dostosowanie stanowiska pracy umożliwiające jej wykonywanie w starszym wieku [19]. Wielką wagę przywiązuje się również do zaangażowania samego pracownika w poprawę własnego stanu zdrowia, który poprzez redukcję nadmiernej masy ciała, zwiększenie oraz dobór właściwej aktywności fizycznej bądź przestrzeganie zaleceń bezpieczeństwa i higieny pracy będzie wzmagał swój kapitał zdrowotny. Kolejny aspekt godny odnotowania, to nieco dłuższy średni czas hospitalizacji chorych z bólem grzbietu w naszym kraju (średnio o 4 dni w stosunku do państw Europy Zachodniej). Biorąc pod uwagę niedostatek środków finansowych w budżecie przeznaczonym na zdrowie, a także wzrost liczby osób z rozpoznaniem choroby, należy uznać, że staje się ona wyzwaniem dla nowego zdrowia publicznego.

\section{PIŚMIENNICTWO}

1. World Health Organization, Program and Projects, Health statistics and health information systems, Mortality and burden of disease attributable to selected major risks. WHO 2004-2009. http://www.who.int/chp/ chronic_disease_report/media (19.05.2011).

2. Chronic diseases and their risk factors - a global burden. SmartGlobalHealth.org 2010. http://www.smartglobalhealth.org/issues/entry/ chronic-diseases/ (14.07.2013).

3. Eurostat. Statistics Database - Health Care. http://epp.eurostat.ec.europa. eu/portal/page/portal/health/public_health (11.06.2014).

4. Olafsson S.: Social and personal costs of arthritis and rheumatic diseases an exploratory survey. Social Research Institute - University of Iceland. 2008. http://www.gigt.is/media/frettir/Social_and_Personal_Costs_of_Rheumatic_Diseases_-endanl.agust081-2.pdf (11.06.2014).

5. Papageorgiou A.C., Croft P.R., Ferry S., Jayson M.I., Silman A.J.: Estimating the prevalence of low back pain in the general population. Evidence from the South Manchester Back Pain Survey. Spine. 1995, 20 (17), 1889-1894.

6. Kent P.M., Keating J.L.: The epidemiology of low back pain in primary care. Chiropr Osteopat. 2005, 26, 13-20.

7. Punnett L., Prüss-Utün A., Nelson D.I., Fingerhut M.A., Leigh J., Tak S. et al.: Estimating the global burden of low back pain attributable to combined occupational exposures. Am J Ind Med. 2005, 48 (6), 459-469.

8. Jones G.T., Macfarlane G.J.: Epidemiology of low back pain in children and adolescents. Arch Dis Child. 2005, 90 (3), 312-316.

9. Loney P.L., Stratford P.W.: The prevalence of low back pain in adults: a methodological review of the literature. Phys Ther. 1999, 79 (4), 384-396.

10. Hoy D., Bain C., Williams G., March L., Brooks P., Blyth F. et al.: A systematic review of the globalprevalence of low back pain. Arthritis Rheum. 2012, 64 (6), 2028-2037.

11. Hoy D., Brooks P., Blyth F., Buchbinder R.: The Epidemiology of low back pain. Best Pract Res Clin Rheumatol. 2010, 24 (6), 769-781.

12. Katz J.N.: Lumbardiscdisorders and low-back pain: socioeconomic factors and consequences. J Bone Joint Surg Am. 2006, 88, Suppl. 2, 21-24.

13. Solecki L.: Wstępna ocena dolegliwości bólowych ze strony układu mięśniowo-szkieletowego, zgłaszanych przez rolników indywidualnych. Poradnik dla lekarzy. Instytut Medycyny Pracy im. prof. J. Nofera w Łodzi, Łódź. 2012, 63 (3), 281-293.

14. Hoy D., March L., Brooks P., WoolfA., Blyth F., Vos T. et al.: Measuring the globalburden of lowbackpain. Best Pract Res Clin Rheumatol. 2010, 24 (2), 155-165.

15. Juniper M., Le T.K., Mladsi D.: The epidemiology, economic burden, and pharmacological treatment of chronic low back pain in France, Germany, Italy, Spain and the UK: a literature - based review. Expert Opin Pharmacother. 2009, 10 (16), 2581-2592.

16. Minta P., Sędziak A., Bugajski A., Sobolak M.: Identyfikacja wpływu niektórych uwarunkowań na wyniki prewencji rentowej w dysfunkcjach narządu ruchu. Poradnik dla lekarzy. Insty tut Medycyny Pracy im. prof. J. Nofera w Łodzi, Łódź. 2012, 63 (2), 167-179.

17. Zakład Ubezpieczeń Społecznych. Departament Statystyki i Prognoz Aktuarialnych. Absencja chorobowa w 2012 roku. http://www.zus.pl/files/ Absencja\%20 chorobowa\%20w\%202012\%20roku\%20.pdf (11.06. 2014).

18. Kwarecki K., Liu D., Zużewicz K.: Czynnik ludzki w bezpieczeństwie pracy. Zmęczenie układu mięśniowo-szkieletowego - stary problem cywilizacyjny. Bezpieczeństwo Pracy. 2000, 9, 28-29.

19. Profilaktyka chorób układu ruchu i obwodowego układu nerwowego wywołanych sposobem wykonywania pracy. Poradnik dla lekarzy. Eds: P. Krawczyk-Szulc, E. Węgrowska-Koski. Instytut Medycyny Pracy im prof. J. Nofera w Łodzi, Łódź. 2010, 53-64. 